\title{
DOBLES o SIN TÍTULO 2
}

\section{EVA ARIZA TRINIDAD y BLANCA ÁLVAREZ DE TOLEDO}

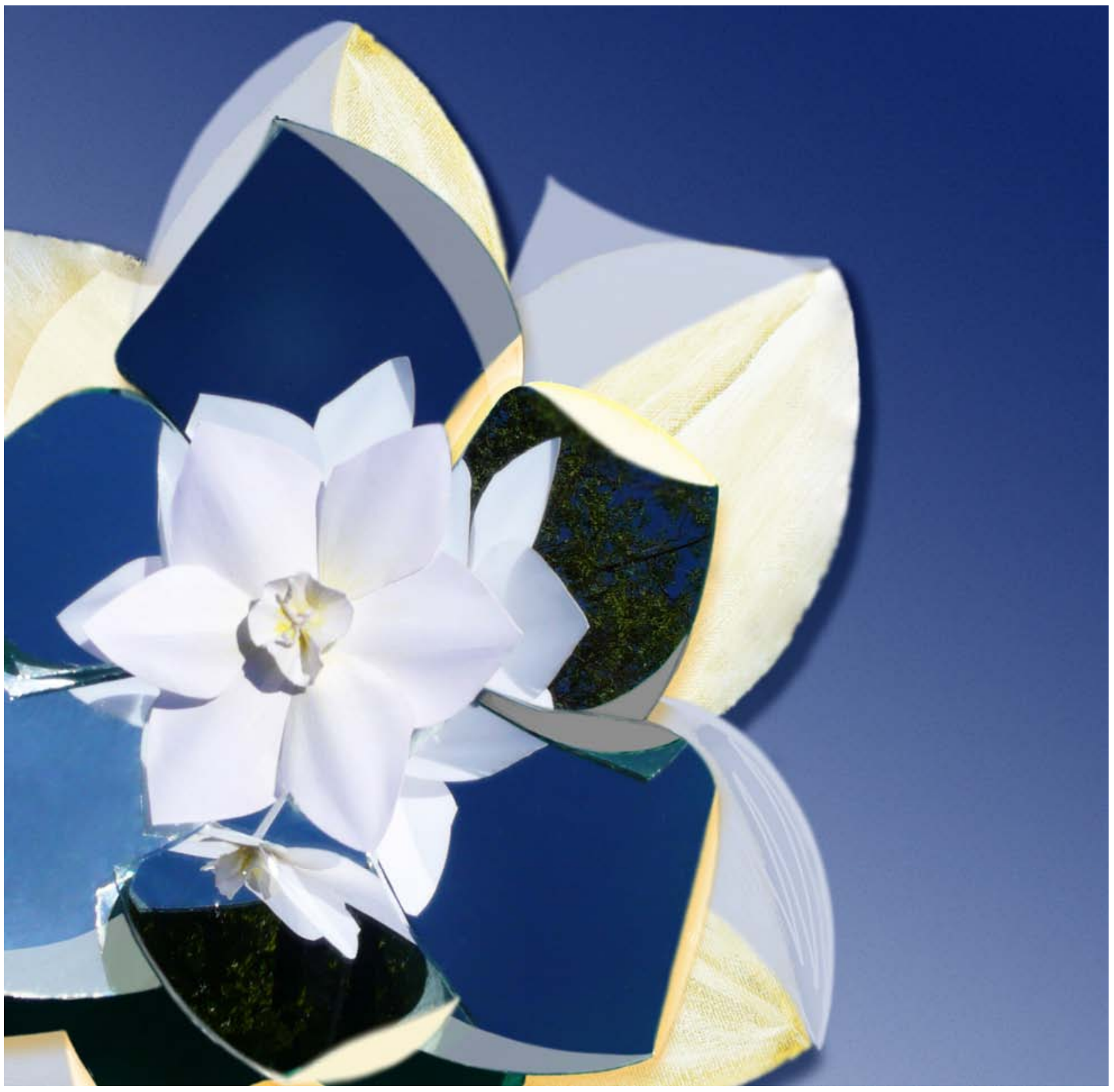

Fecha: 2011

Descripción: Fotomontaje a partir de escultura en vidrio y papel brístol y óleo sobre lienzo. 